Apidologie, 1985, 16 (1), 1-18

\title{
STUDIES ON THE ANNUAL FORAGING CYCLE OF APIS CERANA INDICA F. IN SIMLA HILLS OF NORTHWEST HIMALAYAS
}

\author{
V.K. MATTU and L.R. VERMA \\ Department of Biosciences, Himachal Pradesh University \\ Simla - 171005 (India)
}

\begin{abstract}
SUMMARY
Studies on the foraging behaviour of A.c. indica indicated that pollen and nectar were collected throughout the year irrespective of floral and climatic conditions and thus exhibiting a regular foraging cycle. Foraging activity was greater in summer and autumn as compared to other seasons of the year and the peak of nectar collection activity was generally observed after the peak of pollen collection. Flight behaviour data showed the following hours of peak activity during the various seasons of the year : summer $(0600,0800,1000$ and 1600 hours); rainy $(0900$ and 1000 hours); autumn (0900, 1000 and 1200 hours); early winter (0900 and 1400 hours); late winter (1100 hours) and spring (0800 and 1100 hours).

The percentage of nectar collecto:s was g:eater than those collecting pollen, pollen + nectar and water during all the seasons of the year. Greater fluctuations were noticed in the percentage of nectar collectors as compared to the pollen, pollen + nectar and water collectors during different seasons.
\end{abstract}

\section{INTRODUCTION}

Foraging of honeybees is mainly concerned with the collection of pollen and nectar for the well-being of the colony. Usually a honeybee colony has different sets of worker bees that are conditioned for nectar, pollen, pollen + nectar and water collection (RIBBANDS, 1953). The availability of pollen and nectar to worker bees fluctuates with the time of year and the flowering cycle of the different plants. In the act of foraging for food, honey bees incidentally reciprocate by performing valuable pollination services for the plants.

While a lot of information is available on the foraging spectrum of $A$. mellifera (Ribbands, 1953 ; ERICKSON et al., 1973 ; NúÑEZ, 1977 ; GarY, 1979) very 
little is known about our native bee species, A.c. indica (Cherian et al., 1947 ; Naim and Phadke, 1976 ; Risddy, 1980).

The Simla region of the north-west Himalayas offers a very rich potential for the development of beekeeping because of its vast areas of horticulture, forests and agriculture. It is, therefore, important to have some basic knowledge about the foraging behaviour of A.c. indica F. Such studies could have direct bearing on the pollination of economically important fruit, vegetable and other cereal crops and also in increasing the honey production in this region.

\section{MATERIAL AND METHODS}

The foraging studies were conducted on $A . c$. indica at Simla $\left(31^{\circ}-06^{\prime} \mathrm{N}\right.$ latitude, $77^{\circ}-10^{\prime} \mathrm{E}$ longitude and 2206 metres altitude) for one year from May 1980 to April 1981. The observations were made on five colonies of $A . c$. indica with no signs of disease and no supplemental sugar syrup or pollen was fed to any of the experimental colonies. All the colonies were in two-storey hives with seven frames in the brood chamber and the same number of frames in the super. All the colonies were of similar strength with equal amounts of brood and pollen stores.

The flight activity of worker bees was measured by counting the number of outgoing bees over a 10-minute period at the entrance of the hive each hour throughout the day. The results were expressed as percentage of bees leaving the hive following the method used by KERR et al. (1970). According to this method, flight activity between the initiation and cessation of the study period was taken as 100 percent and from this data, hourly or monthly averages were calculated. Thus each curve or column in different figures represents $100 \%$ of the activity of the bees. Percentage llight activity was calculated as follows :

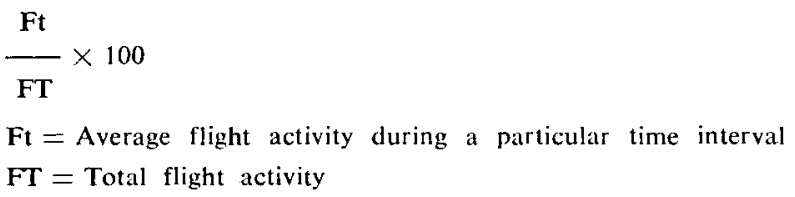

The relative number of bees foraging for pollen, nectar or water were estimated following the method of PARK (1926) and ERICKSON et al. (1973). This was determined by closing the hives for 5 -minutes and collecting 35 to 40 incoming bees at the entrance of the hive with a insect net. These samples were collected once week at regular hourly intervals from 0600 to 1800 hours each month. The samples were sealed in bags and immediately frozen in crushed ice to prevent regurgitation of the nectar. Bees carrying pollen loads in their legs were categorized as pollen collectors. For discrimination between nectar or water collectors, honey sac of each bee was placed out on a Whatmann number 1 filter paper. If no visible stain was found after drying on the filter paper, it was considered to be water collector otherwise, categorized as nectar collector. Bees with both nectar and pollen loads were named as pollen + nectar collectors and those without any load as empty bees.

In order to study the seasonal variations in the foraging activity patterns, experiments were carried out in summer (May-June); rainy (July-August); autumn (September-October); early winter (November-December) ; late winter (January-February) and spring (March-April) (Fig. 1). 


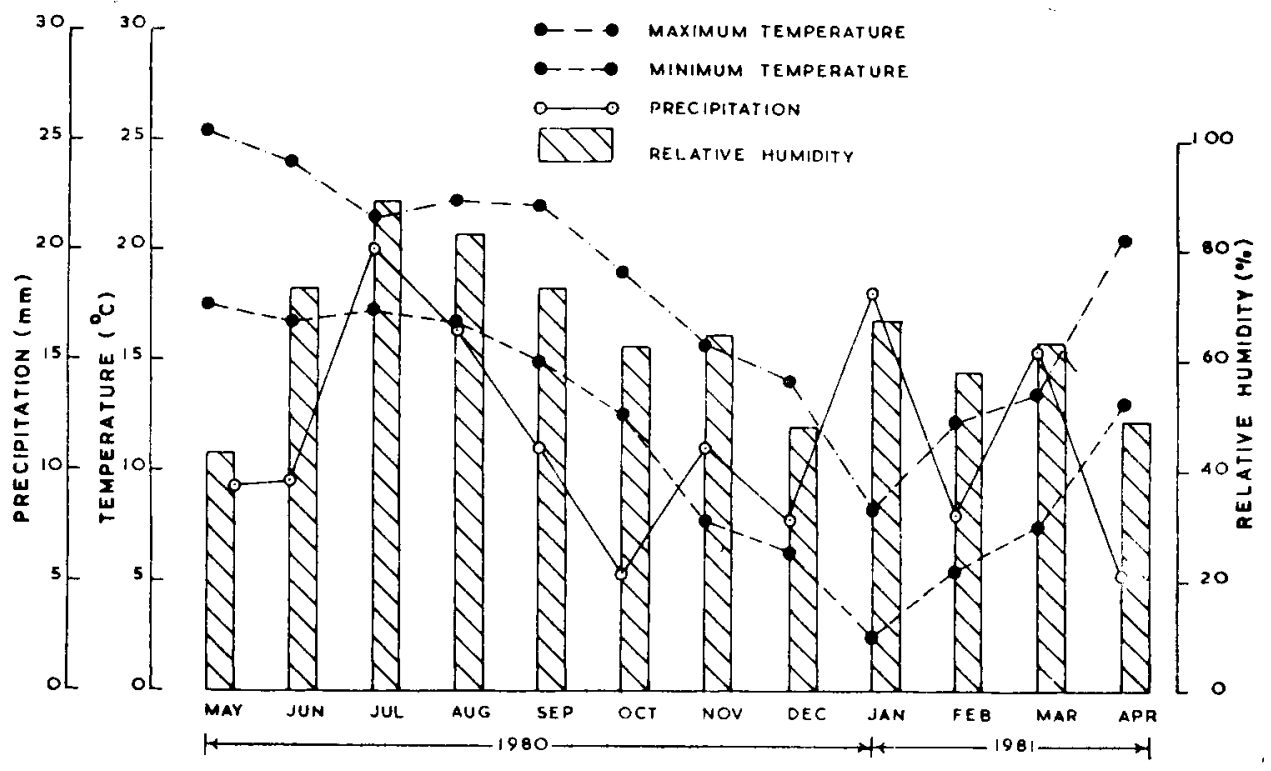

Fic. 1. - Meteorological details of Simla region during one year of study (May 1980 to April 1981).

Relative humidity was determined by hair hygrometer.

\section{RESULTS}

The foraging behaviour of A.c. indica showed variations in the different seasons of the year as follows :

\section{1) Summer season}

In this season, flight activity started early in the morning (mean time 0506 hours in May and 0500 hours in June) and ended very late in the evening (mean time 1925 hours in May and 1938 hours in June) (fig. 2). Flight activity was greater in May $(12.28 \%)$ as compared to June $(10.27 \%$ ) (fig. 3). The peak hours of flight activity were at $0600(11.31 \%), 0800(9.45 \%), 1000(8.98 \%)$ and $1600(7.43 \%)$ hours (fig. 4). 


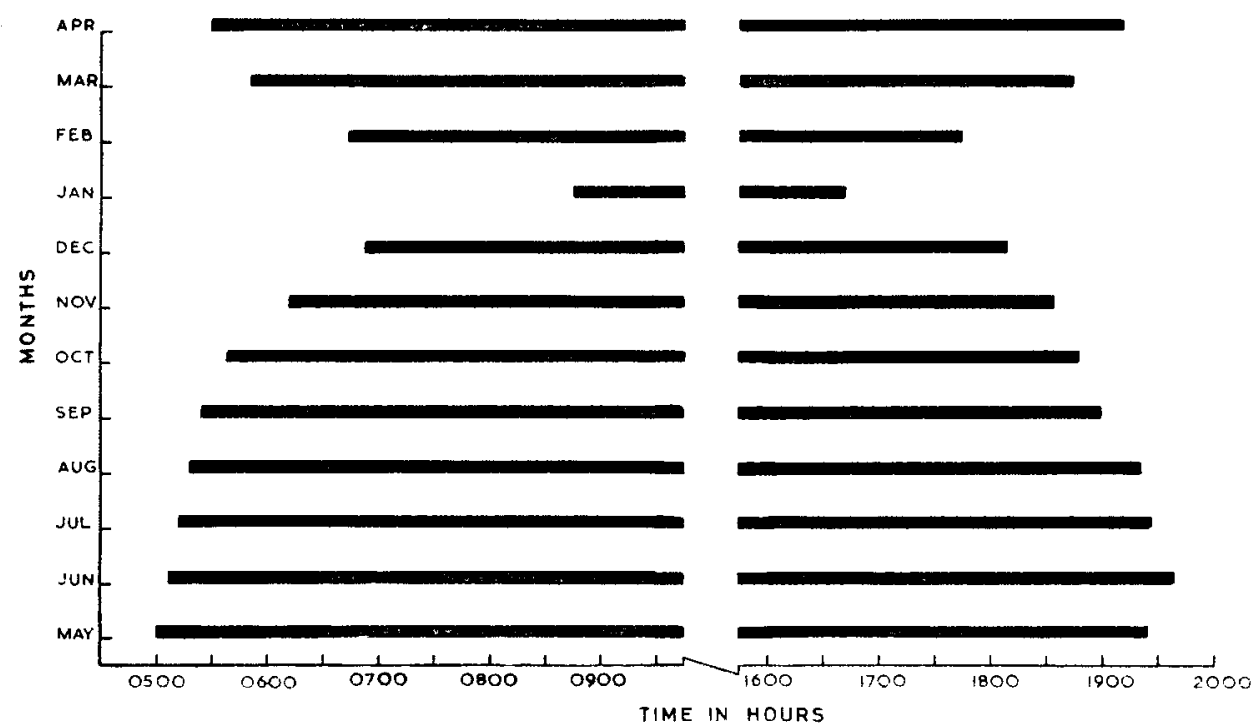

FIG. 2. - Seasonal variations in the time of initiation and cessation of flight activity of worker bees of A.c. indica.
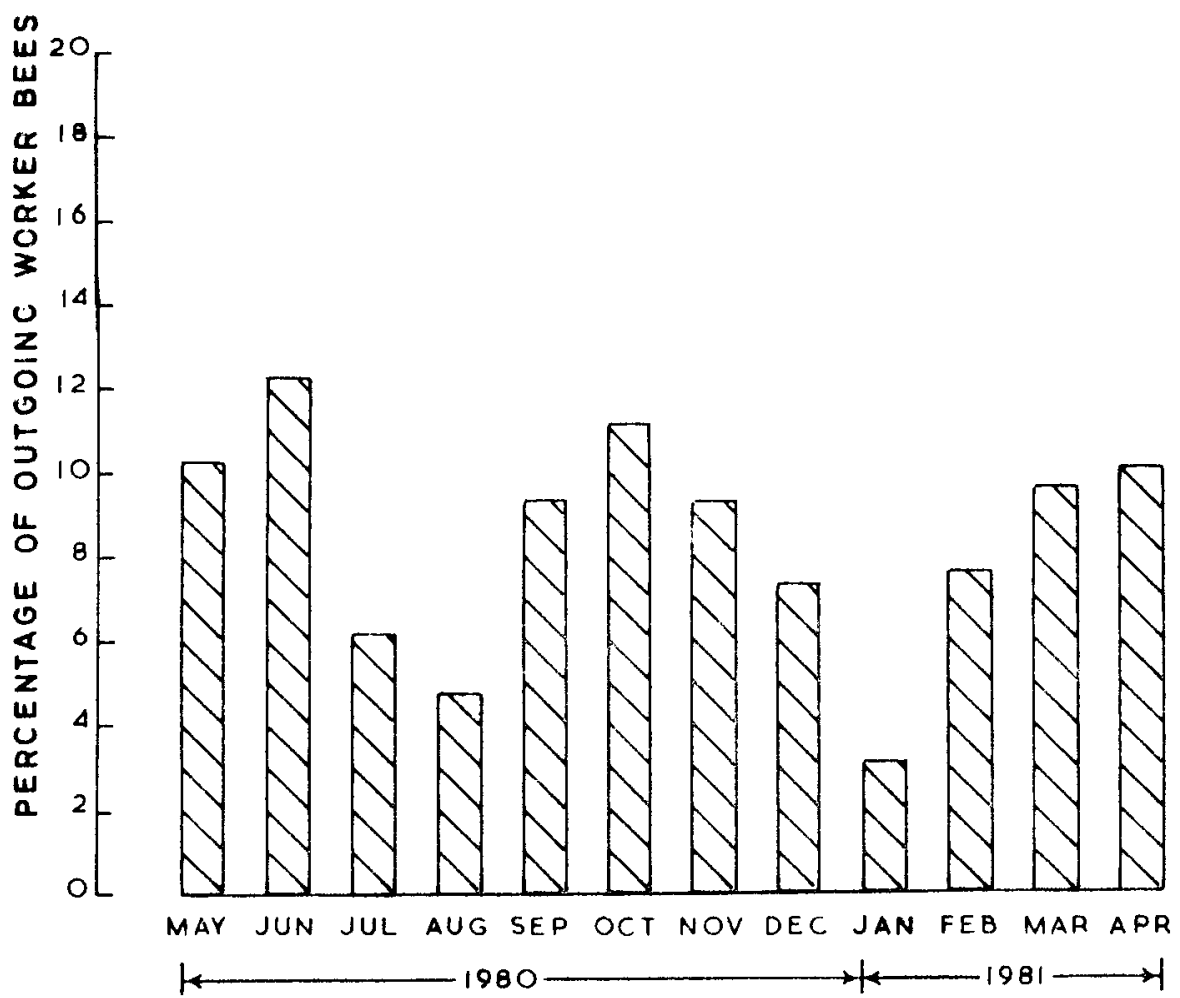

\section{MONTHS}

FIG. 3. - Seasonal variations in the percentage of outgoing worker bees of A.c. indica during different months of the year. 


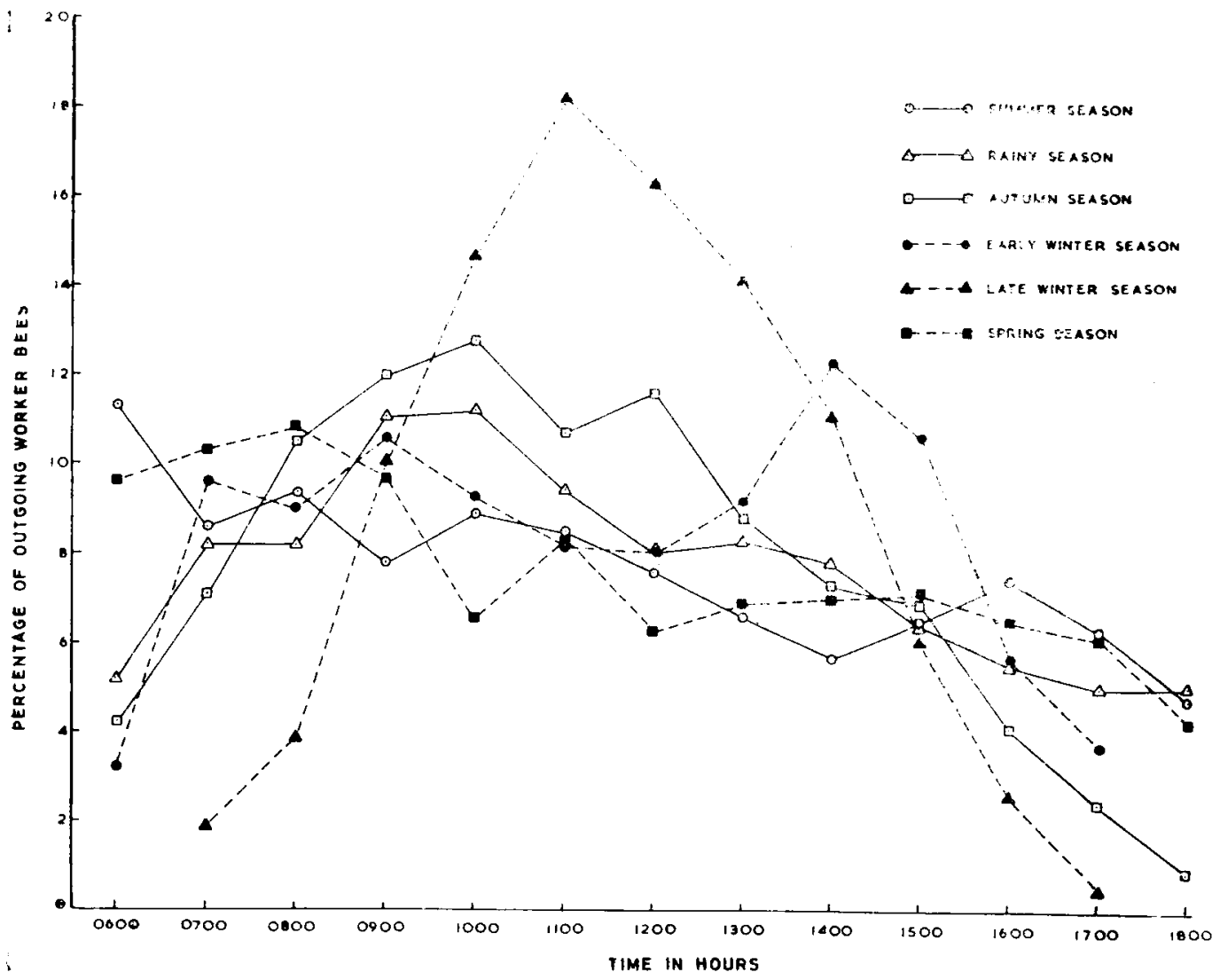

FIg. 4. - Seasonal variations in the percentage of outgoing worker bees of A.c. indica at different hours of the day during different seasons of the year.

The percentage of bees collecting pollen, nectar, pollen + nectar, water loads and without any load was as follows :

May

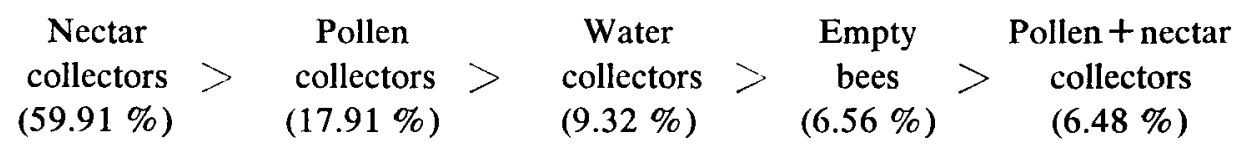

A similar pattern of foraging was also observed in June. The percentage of pollen, pollen + nectar and water collectors was higher in May, whereas in June the percentage of bees returning with nectar and without and load was greater (fig. 5). 


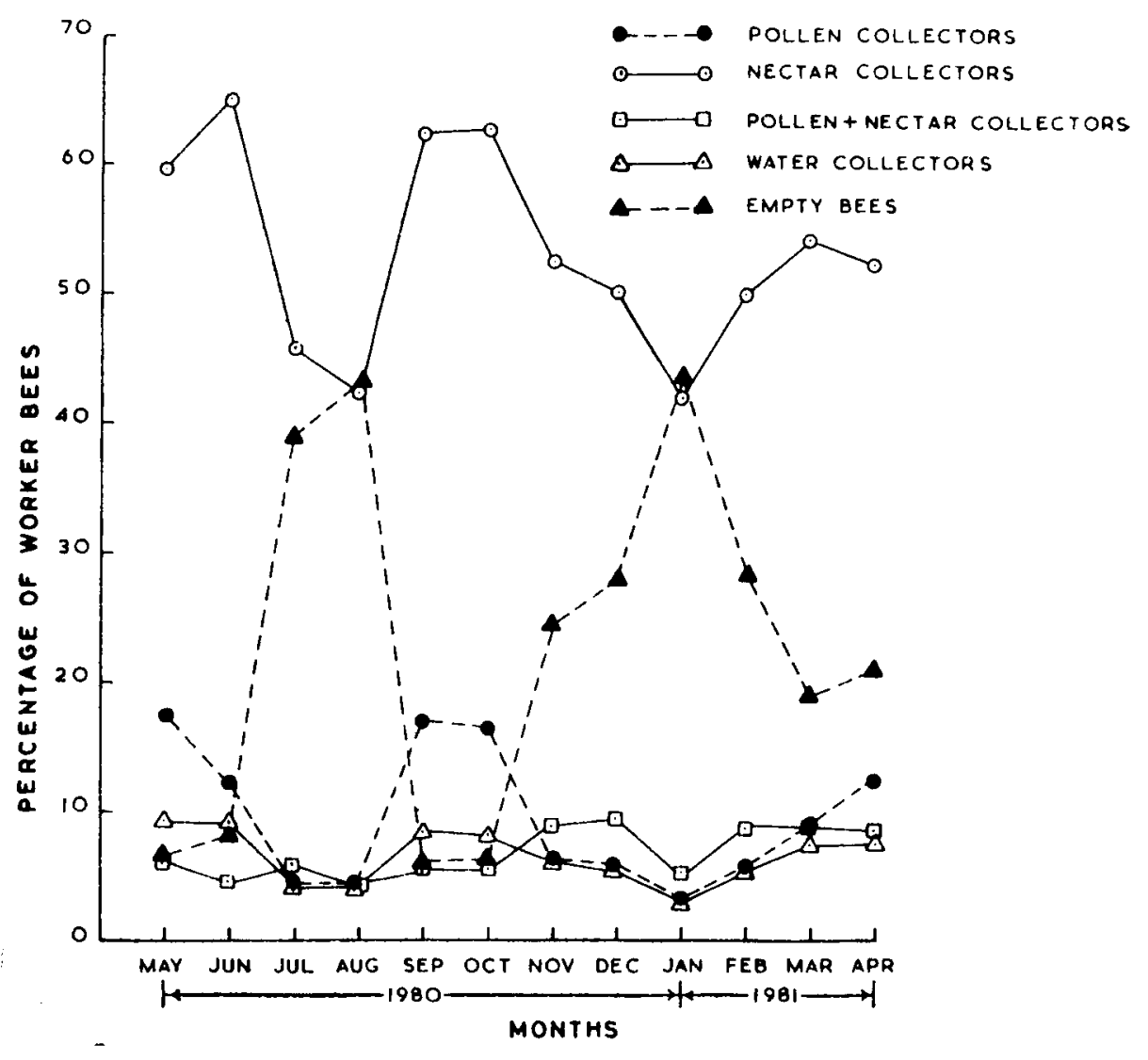

FIG. 5. - Seasonal variations in the percentage of pollen, nectar, pollen + nectar, water collectors and empty bees of A.c. indica at different months of the year.

Pollen collection activity was greater at $0600(22.97 \%), 0700(21.75 \%)$, $1000(20.81 \%)$ and $1100(21.08 \%)$ hours except for a secondary peak at 1600 $(12.43 \%)$ hours after which it decreased steadily. There were two peaks of nectar collecting activity at $0800(74.32 \%)$ and $1400(67.56 \%)$ hours. The percentage of water collectors was higher at $0900(12.70 \%), 1000(12.16 \%), 1300$ $(14.18 \%)$ and $1500(17.70 \%)$ hours. There were no wide fluctuations in the percentage of pollen + nectar collectors during the different hours of the day (fig. 6). 


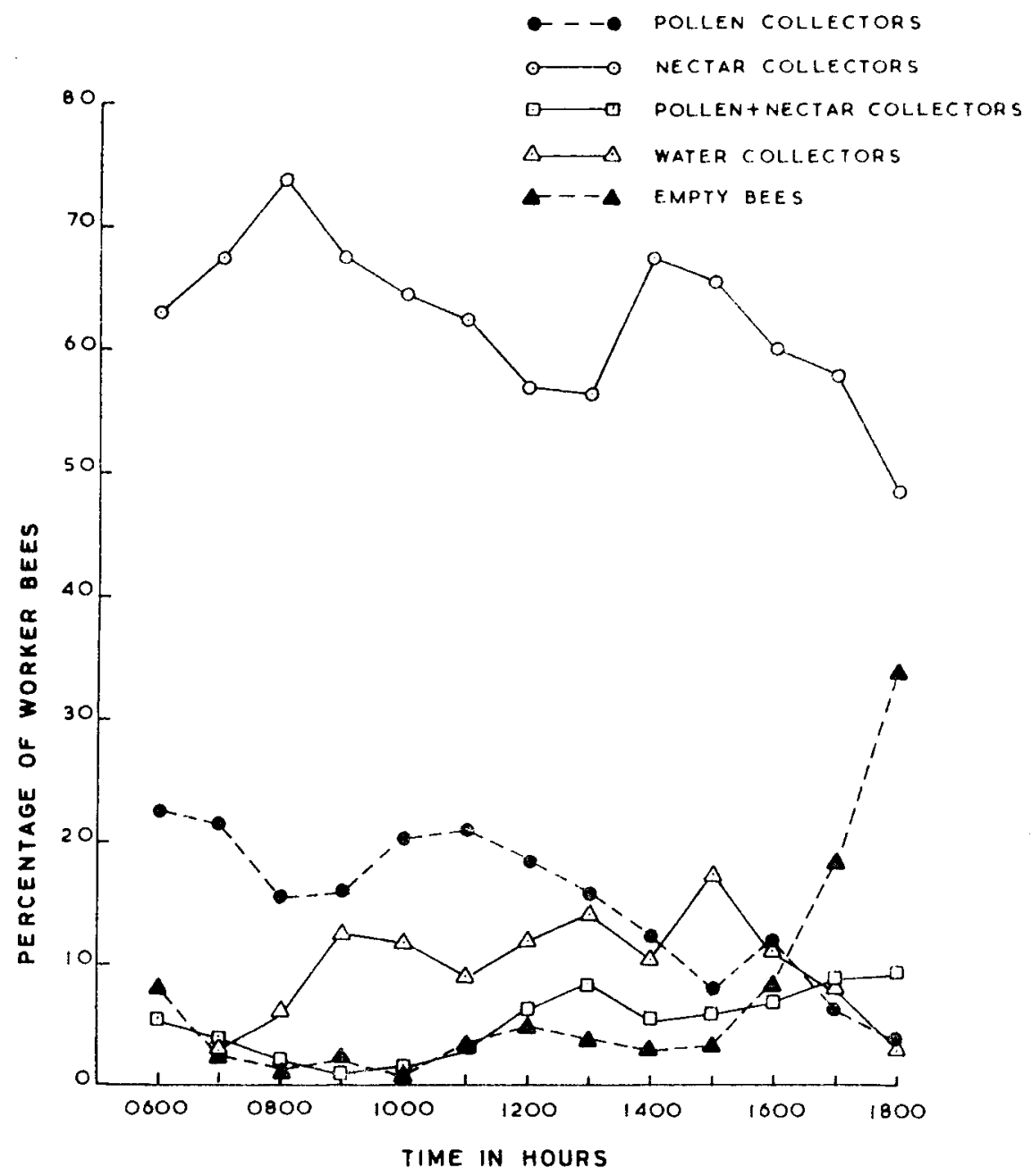

Fig. 6. - Summer season. Percentage of pollen, nectar, pollen + nectar, water collectors and empty bees of A.c. indica at different hours of the day.

2) Rainy season

The mean time of initiation and cessation of flight activity by worker bees was 0512 and 1926 hours respectively in July and 0518 and 1920 hours in August (fig. 2). The flight activity was greater in July $(6.17 \%)$ than in August $(4.74 \%)$ (fig. 3). Flight activity was maximum at $0900(11.07 \%)$ and $1000(11.26 \%$ ) hours (fig. 4). 
In the rainy season bees returning to the hive with and without any load (empty bees) showed the following trend :

July

$\begin{gathered}\begin{array}{c}\text { Nectar } \\ \text { collectors }\end{array} \\ (46.18 \%)\end{gathered} \begin{gathered}\text { Empty } \\ \text { bees } \\ (39 \%)\end{gathered} \quad \begin{gathered}\text { Pollen + nectar } \\ \text { collectors } \\ (5.81 \%)\end{gathered} \begin{gathered}\text { Pollen } \\ \text { collectors }\end{gathered}>\begin{gathered}\text { Water } \\ \text { collectors } \\ (4.83 \%)\end{gathered}$

August

$\begin{gathered}\text { Empty } \\ \text { bees }\end{gathered}>\begin{gathered}\text { Nectar } \\ \text { collectors } \\ (43.24 \%)\end{gathered} \quad \begin{gathered}\text { Pollen + nectar } \\ \text { collectors } \\ (42.59 \%)\end{gathered} \quad \begin{gathered}\text { Pollen } \\ (4.91 \%)\end{gathered} \begin{gathered}\text { Wollectors } \\ (4.64 \%)\end{gathered} \quad \begin{gathered}\text { Wollectors } \\ (4.54 \%)\end{gathered}$

In July the percentage of nectar collectors was higher than empty bees but in August the reverse was true. Pollen, pollen + nectar and water collectors did not show much variations in their percentage during the different months of this season (fig. 5).

Pollen collection activity peaked at $1000(9.32 \%)$ hours and nectar collectors showed two peaks of activity at $0900(50 \%)$ and $1400(52.16 \%)$ hours. The percentage of empty bees was highest at $0600(53.24 \%)$ and $1800(52.70 \%)$ hours. The water collectors also showed two peaks of activity at $0900(8.10 \%)$ and $1200(8.24 \%)$ hours. There was very little variation in the percentage of pollen + nectar collectors (fig. 7).

\section{3) Autumn season}

In the autumn, flight activity started at 0525 and 0538 hours and ceased at 1900 and 1848 hours in September and October respectively (fig. 2). This activity was greater in October $(11.12 \%)$ than in September $(9.31 \%)$ (fig. 3). The maximum flight activity was observed at $0900(12.03 \%) ; 1000(12.84 \%)$ and $1200(11.63 \%)$ hours (fig. 4).

The ranking of pollen, nectar, pollen + nectar, water collectors and empty bees returning to the hive during this season was as follows :

September

\begin{tabular}{|c|c|c|c|c|}
\hline $\begin{array}{c}\text { Nectar } \\
\text { collectors } \\
(62.59 \%)\end{array}$ & $\begin{array}{c}\text { Pollen } \\
\text { collectors } \\
(17.10 \%)\end{array}$ & $\begin{array}{c}\text { Water } \\
\text { collectors } \\
(8.64 \%)\end{array}$ & $\begin{array}{c}\text { Empty } \\
\text { bees } \\
(6.37 \%)\end{array}$ & $\begin{array}{c}\text { Pollen + nectar } \\
\text { collectors } \\
(5.78 \%)\end{array}$ \\
\hline
\end{tabular}




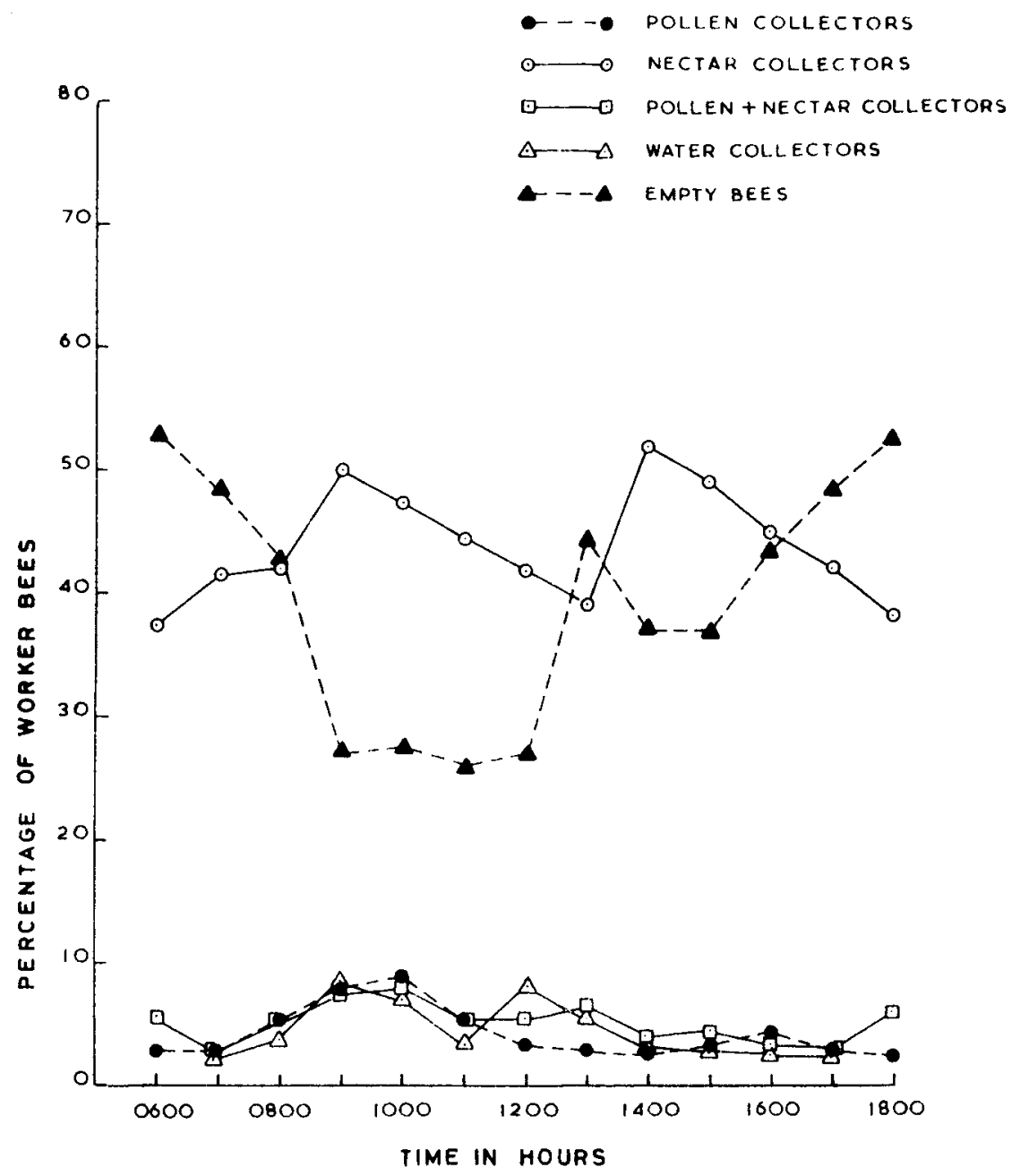

FIG. 7. - Rainy season. Same legend as Fig. 6.

The ranking in October was similar to that of September. Very little variation was seen in the percentage of bees performing different activities during this season (fig. 5).

The peak in pollen collection activity was observed at $1000(29.72 \%)$ hours, whereas, the maximum percentage of nectar collectors was observed at 1100 $(66.21 \%)$ and $1500(73.37 \%)$ hours. The water collectors peaked at 1000 $(12.83 \%), 1200(10.13 \%)$ and $1400(15.40 \%)$ hours, whereas, the maximum percentage of pollen + nectar collectors was at $0800(13.10 \%), 1600(7.70 \%)$ and $1700(7.56 \%)$ hours (fig. 8). 


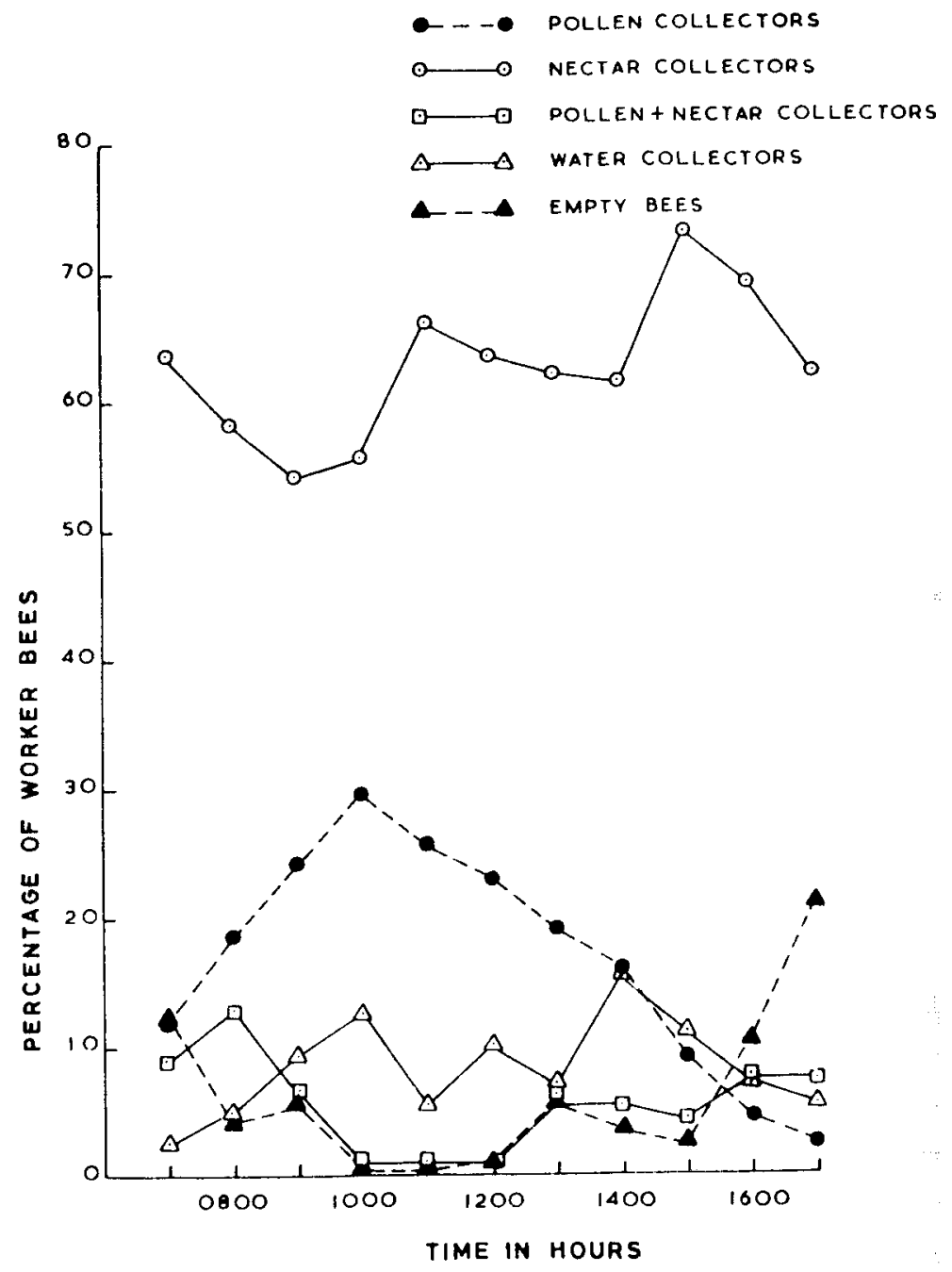

FiG. 8. - Auiumn season. Same legond as Fig. 6.

4) Early winter season

The mean time for initiation and cessation of flight activity was 0614 and 1835 hours in November and 0653 and 1809 hours in December respectively (fig. 2). The flight activity was greater in November (9.33\%) than in December $(7.30 \%)$ (fig. 3) and the peak period of activity were at $0900(10.62 \%)$ and $1400(12.32 \%)$ hours (fig. 4). 
The percentage of bees returning to the hive with different loads and without any load was as follows :

November

$\begin{gathered}\begin{array}{c}\text { Nectar } \\ \text { collectors } \\ (52.54 \%)\end{array} \\ \text { bees } \\ (24.72 \%)\end{gathered}>\begin{gathered}\text { Pollen + nectar } \\ \text { collectors } \\ (9.10 \%)\end{gathered}>\begin{gathered}\text { Pollen } \\ \text { zollectors } \\ (6.94 \%)\end{gathered}>\begin{gathered}\text { Water } \\ \text { collectors } \\ (6.59 \%)\end{gathered}$

A similar ranking was also observed for December. In this season, nectar and water collectors were higher in November than in December. However, the percentage of empty bees increased in December. All other categories of foraging activities did not show much variation during this season (fig. 5).

Pollen collecting activity was at its maximum at $1100(11.48 \%)$ and 1200 $(11.48 \%)$ hours, whereas, the peak of nectar collecting was at $1300(62.83 \%)$ hours. Pollen + nectar collecting peaked at $1200(15.27 \%)$ hours with a secondary peak at $1500(11.08 \%)$ hours. The maximum number of water collectors was observed at $1200(9.45 \%), 1300(9.72 \%)$ and $1400(10 \%)$ hours and the percentage of empty bees was maximum at $0800(50 \%)$ and $1600(43.21 \%)$ hours (fig. 9).

\section{5) Late winter season}

During this season, foraging by bees started and ceased at 0850 and 1643 hours in January and 0643 and 1745 hours in February respectively (fig. 2). There was more flight activity in February $(6.62 \%)$ than in January (3.15\%) (fig. 3) and the peak period of flight was at 1100 (18.27\%) hours (fig. 4).

The ranking of pollen, nectar, pollen + nectar, water collectors and empty bees returning to the hive during this season was as follows :

January

$\left.\begin{array}{c}\text { Empty } \\ \text { bees } \\ (43.49 \%)\end{array}>\begin{array}{c}\text { Nectar } \\ \text { collectors } \\ (42.32 \%)\end{array}>\begin{array}{c}\text { Pollen + nectar } \\ \text { collectors } \\ (5.13 \%)\end{array} \begin{array}{c}\text { Water } \\ \text { collectors }\end{array}>\begin{array}{c}\text { Pollen } \\ \text { collectors } \\ (4.94 \%)\end{array}\right)$

February

\begin{tabular}{|c|c|c|c|c|}
\hline $\begin{array}{c}\text { Nectar } \\
\text { collectors } \\
(50.13 \%)\end{array}$ & $\begin{array}{c}\text { Empty } \\
\text { bees } \\
(28.91 \%)\end{array}$ & $\begin{array}{c}\text { Pollen }+ \text { nectar } \\
\text { collectors } \\
(9.27 \%)\end{array}$ & $\begin{array}{l}\text { Pollen } \\
\text { collectors } \\
(6 \%)\end{array}$ & $\begin{array}{c}\text { Water } \\
\text { collectors } \\
(5.62 \%)\end{array}$ \\
\hline
\end{tabular}

In February there was a higher percentage over January in all categories of bees (fig. 5). 


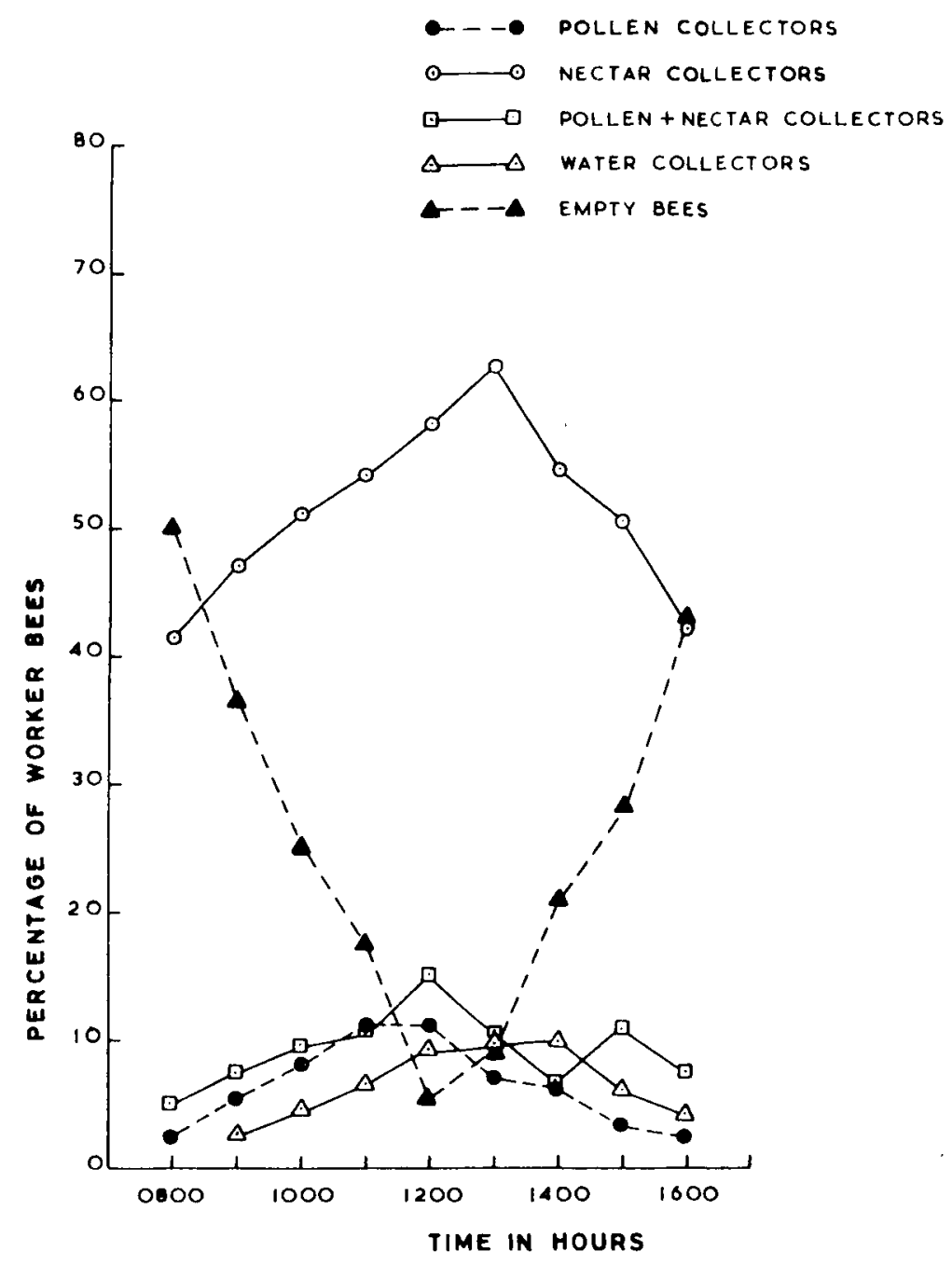

FIG. 9. - Early winter season. Same legend as Fig. 6.

The maximum pollen collection activity was observed at $1000(7.5 \%)$ and $1200(8.78 \%)$ hours. Nectar collectors peak period of activity was at 1400 $(56.08 \%)$ hours. Empty bees showed maximum activity at $0800(49.45 \%)$ and $1600(48.64 \%)$ hours. Pollen + nectar collectors were found in maximum number at $0900(10 \%)$ and $1300(11.08 \%)$ hours. The peak periods of water collection was at $1200(8.10 \%)$ and $1300(8.78 \%)$ hours (fig. 10). 


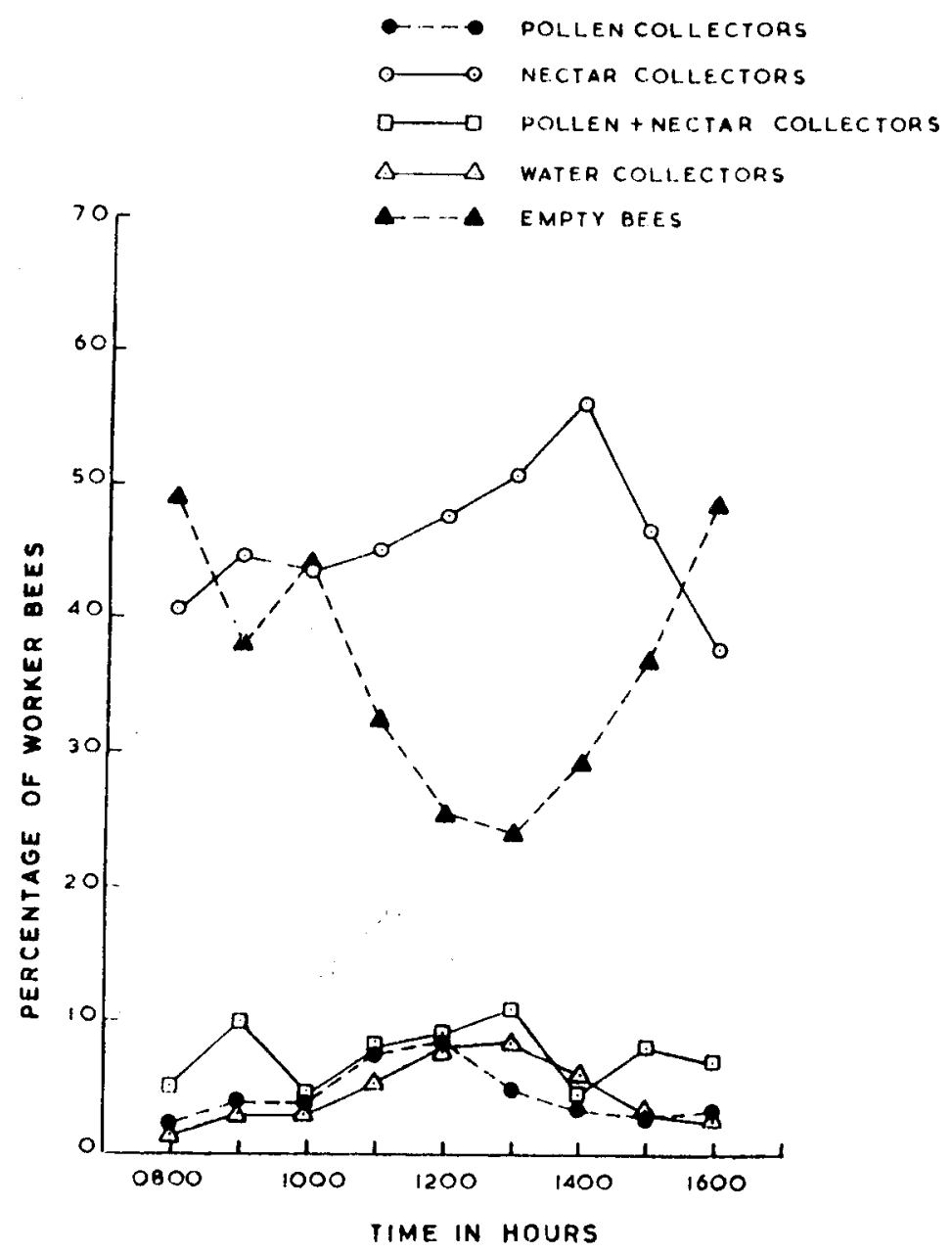

FIG. 10. - Late winter season. Same legend as Fig. 6.

6) Spring season

In the spring flight activity began and ended at 0550 and 1845 hours in March and 0530 and 1912 hours in April respectively (fig. 2). More flight activity was observed in April (10.07\%) than in March (9.65\%) (fig. 3) and the maximum flight activity was recorded at $0800(10.89 \%)$ hours with a secondary peak at $1100(8.31 \%)$ hours (fig. 4).

Different categories of bees returning to the hive showed the following sequence :

March

$\begin{gathered}\text { Nectar } \\ \text { collectors } \\ (54.29 \%)\end{gathered}>\begin{gathered}\text { Empty } \\ \text { bees } \\ (19.10 \%)\end{gathered}>\begin{gathered}\text { Pollen } \\ \text { collectors } \\ (9.37 \%)\end{gathered}>\begin{gathered}\text { Pollen + nectar } \\ \text { collectors }\end{gathered}>\begin{gathered}\text { Water } \\ \text { collectors } \\ (9.18 \%)\end{gathered}$


A similar pattern of foraging was also observed in April. Only small variations in their percentage was observed during the different months of this season (fig. 5).

The maximum pollen collection was observed at $0900(20.27 \%)$ and a secondary peak was seen at $1500(10.54 \%)$ hours. Nectar collectors were seen in maximum numbers at $0800(62.16 \%)$ and $1300(59.86 \%)$ hours. Water collectors peaked at $1000(13.51 \%), 1100(12.16 \%)$ and $1300(10.54 \%)$ hours. The percentage of bees with pollen + nectar loads was highest at $1100(14.86 \%)$ and $1500(11.21 \%)$ hours. Empty bees were found in maximum numbers at 1700 (10.13\%) hours (fig. 11).

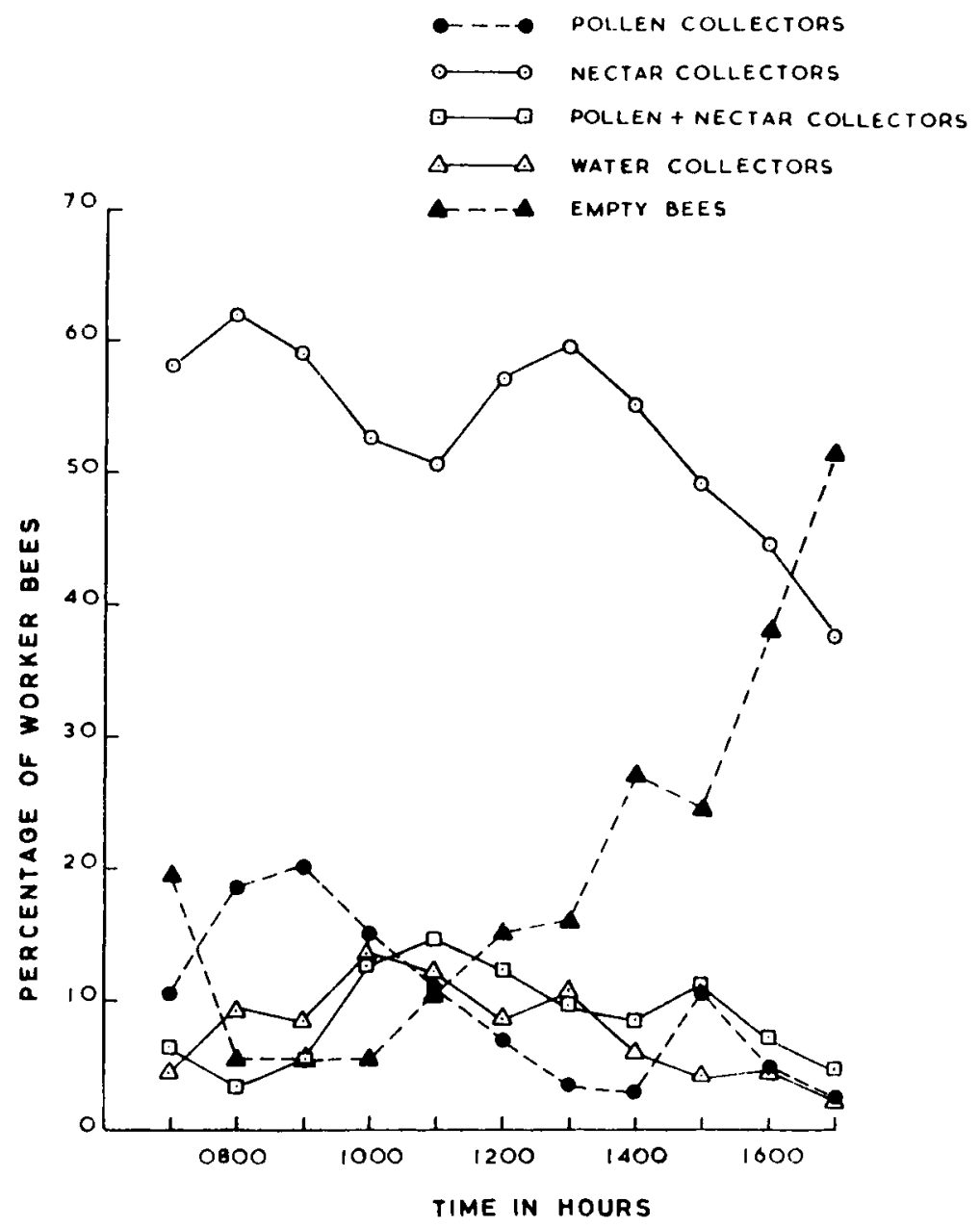

Fig. 11, - Spring season. Same legend as Fig. 6. 


\section{DISCUSSION}

The present data indicated that the foraging activity of A.c. indica was greater in summer and autumn than in the rainy and winter seasons (figs. 3, 5). This may be due to the favourable weather in the summer and autumn which results in the maximum honeyflow conditions due to the availability of a large number of bee plants. In the summer and autumn, greater flight activity may also be due to higher population of bees in the hives. In the rainy season, because of continuous monsoon and foggy weather, the percentage of bees leaving the hive was low, whereas, in the winter, foraging activity may be at its lowest due to scaracity of bee flora and low ambient temperature (fig. 1). A number of investigators have reported different periods of maximum and minimum foraging activity from various parts of India. For example, maximum foraging activity was reported in November to February (Coimbatore, South India) ; January (Delhi) ; January to March (Pusa, Bihar); July (Bangalore, South India) and minimum foraging was reported in October (Coimbatore, South India); May to July (Delhi) ; July to October (Pusa, Bihar) ; and January (Bangalore, South India) (ChERIAN et al., 1947 ; Bisht, 1966 ; Naim and Phadke, 1976 ; Reddy, 1980). These variations in the results may be due to the different climatic and floral conditions in the country.

The results on the water collection activity of $A . c$. indica $\mathrm{F}$. indicated that peak water collection was in May (summer) and the low point was in January (late winter) (fig. 3). This may be because in the summer more water is needed for cooling the hive and also for diluting the honey.

The flight activity of A.c. indica F. started early in the morning (mean time, 0503 hours) and ended very late in the evening (mean time, 1932 hours) during the summer (fig. 2). Similar results were also reported by other investigators for this species from South India (Cherian et al., 1947 ; Subbaredd et al., 1980). In the present investigation, after the summer, the initiation of flight was delayed and bees also ceased foraging earlier in the rainy, autumn, and winter seasons (fig. 2). These changes in the time of initiation and cessation of flight activity during different seasons may be related to light intensity, temperature nectar secretion and pollen dehiscence.

In the summer, greatest flight activity was observed at 0600,0800 and 1000 hours in the morning while in the evening it was at 1600 hours (fig. 3). The activity maxima in the morning may be related to the availability of the nectar. Our results also suggested variations in the periods of maximum flight activity during rainy (0900 and 1000 hours) ; autumn (0900, 1000 and 1200 hours) ; early winter (0900 and 1300 hours); late winter (1100 hours) and spring (0800 and 1100 
hours) (fig. 3). These differences may be related to the changing weather and bee forage. Cherian et al. (1947) also reported maximum flight activity from 0600 to 0800 hours in the summer and 0900 to 1000 hours in the early winter in South India.

The studies on the relative ranking of pollen, nectar and water collection activity revealed that nectar collection was maximum at 0800 and 1300 hours in spring season (fig. 11). However, Cherian et al. (1947) observed only one peak of nectar collection (0600 to 0800 hours) for a similar period in Coimbatore (South India). Our studies indicated only one peak of nectar collection (1300 hours) in early winter (fig. 9), whereas, Cherian et al. (1947) reported two peaks of nectar collection (0900 and 1200 hours) for this species from South India during the same season.

Our results showed two peaks of pollen collection at 0900 and 1500 hours during spring season (fig. 11) whereas, NúNEZ (1977) reported only one peak of pollen collection at 1000 hours for $A$. mellifera in Venezuela. We also observed in other seasons, peak periods of pollen collection at 0600, 0700, 1000, 1100 and 1600 hours (summer); 1000 hours (rainy); 1000 hours (autumn); 1100 and 1200 hours (early winter) and 1100 and 1200 hours (late winter). Nectar collection maxima was observed at 0800 and 1400 hours (summer); 0900 and 1400 hours (rainy) ; 1100 and 1500 hours (autumn); 1300 hours (early winter) and 1400 hours (late winter) (figs. 6 to 11). These may be due to the variations in time of the availability of pollen and nectar from different plant species during each season of the year and environmental factors such as temperature, light intensity, humidity, etc.

In the spring, peak periods of pollen collection activity (0900 and 1800 hours) were observed after the peak period of nectar collection activity (0800 and 1300 hours) thus representing a predictable foraging cycle (fig. 11). NúNEZ (1977) also reported similar results for $A$. mellifera $\mathrm{L}$. but BENNETT and RENNER (1963) observed sudden changes in percentage of pollen and nectar collectors. However, in the present investigations, in all seasons, peak nectar collection was observed after peak pollen collection (figs. 6 to 10 ).

The present foraging data suggested that percentage of nectar collectors was greater than those collecting pollen and pollen + nectar in all the seasons of the year and greater seasonal variations were observed in percentage of nectar collectors as compared to other categories of foraging bees (figs. 5 to 11). Other investigators have also found similar pattern for A.c. indica F (CHERIAN et al., 1947) and $A$. mellifera (ERICKSON et al., 1973) except for the observations of REDDY (1980) who recorded pollen + nectar collectors in greatest number and reported a greater seasonal variations in pollen over nectar collectors in South 
India. Our observations on the water collectors (fig. 5) agreed with the observations of NúNEz (1977) for $A$. mellifera $\mathrm{L}$. who also observed three maxima of water collectors at 0800,1100 and 1500 hours in the spring.

Received for publication in October 1983.

Accepted for publication in November 1984.

\author{
RESUME \\ ETUDE DU CYCLE ANNUEL DE BUTINAGE D'AFIS CERANA INDICA F. \\ DANS LES COLLINES DE SIMLA (NORD-OUEST DE L'HIMALAYA)
}

Les études de butinage ont été menées sur Apis cerana indica $F$. dans la région de Simla (partie nord-ouest de l'Himalaya) durant l'été, la saison des plujes, le début et la fin de l'hiver et le printemps de mai 1980 à avril 1981 (Fig, 1). Les observations ont porté sur 5 colonies d'Apis ceiana indica de force égale. Les colonies expérimentales n'ont montré aucun signe de maladie et n'ont reçu aucun nourrissement supplémentaire, ni sirop de sucre ni pollen.

On a mesuré l'activité de vol des ouvrières en comptant à l'entrée de la ruche, pendant $10 \mathrm{mn}$ toutes les heures et durant toute la journée, le nombre d'abeilles qui sortaient. On a déterminé le nombre relatif de batineuses de pollen et de butineuses de nectar en claustrant la ruche pendant 5 minutes et en prélevant 35-40 ouvrières qui rentraient, à 1 heure d'intervalle de $6 \mathrm{~h}$ à $18 \mathrm{~h}$. Elles étaient alors classées en butineuses de pollen, de nectar, de pollen + nectar, d'eau ou d'ouvrières sans charge.

Les études sur le comportement de butinage d'Apis cerana indica montrent que le pollen et le nectar sont récoltés toute l'année, indépendamment des conditions florales et climatiques. A.c. indica présente donc un cycle de butinage régulier. L'activité de butinage est plus forte en été et à l'automne par rapport aux autres saisons de l'année (Figs 3 et 5). Le maximum de l'activité de récolte du nectar a lieu en général apiès celui de l'activité de récolte du pollen. Les heures d'activité de butinage maximale pour les diverses saisons sont les suivantes : été $(6 \mathrm{~h}, 8 \mathrm{~h}, 10 \mathrm{~h}$ et $16 \mathrm{~h})$, saison des pluies $(9 \mathrm{~h}$ et $10 \mathrm{~h}$ ), automne $(9 \mathrm{~h}, 10 \mathrm{~h}$ et $12 \mathrm{~h})$, début de l'hiver $(9 \mathrm{~h}$ et $12 \mathrm{~h})$, fin de l'hiver $(11 \mathrm{~h})$ et printemps $(8 \mathrm{~h}$ et $11 \mathrm{~h})$ (Fig. 4$)$.

Les butineuse de nectar sont plus nombreuses, en pourcentage, que les butineuses de pollen, de pollen + nectar et d'eau, à toutes les saisons. On a noté de plus grandes variations dans le pourcentage des butineuses de nectar par rappo:t aux autres butineuses, aux différentes saisons (Figs 6 à 11).

\title{
ZUSAMMENFASSUNG
}

\section{STUDIE ÜBER DEN JAHRLICHEN TRACHTZYKLUS DER INDISCHEN HONIGBIENE APIS CERANA INDICA F. IM BERGLAND VON SIMLA (NORD-WEST-HIMALAYA)}

Die Studien über die Trachtzeiten von Apis cerana indica F. wurden in der Region von Simla im nordwestlichen Himalaya im Sommer, zur Regenzeit, im Herbst, frühen Winter, späten Winter und Frühling von Mai 1980 bis April 1981 durchgeführt (Fig. 1). Die Beobachtungen wurden an 5 etwa gleich starken Kolonien von Apis cerana indica gemacht. Es gab keine Hinweise auf Krankheiten der Versuchsvölker während der Versuchszeit und es wurde weder Zucker noch Pollen zusätzlich gefüttert. 
Die Flugaktivität der Arbeitsbienen wurde durch Zählen der an- und abfliegenden Bienen am Stockeingang je 10 Minuten pro Stunde während des ganzen Tages protokolliert. Die relative Anzahl der Nektar bzw. Pollen sammelnden Bienen wurde folgendermaßen bestimmt : Der Bienenstock wurde in regelmäßigen, stündlichen Abstäinden (von $6.00 \mathrm{~h}$ bis $18.00 \mathrm{~h}$ ) je 5 Minuten lang geschlossen und 35-40 anfliegende Bienen abgesammelt. Diese wurden dann in folgende Klassen eingeteilt : Pollen-, Nektar-, Pollen + Nektar und Wasser-sammlerinnen oder «leere- Bienen.

D:e Studien des Trachtverhaltens der indischen Honigbiene ergaben, daß Pollen und Nektar während des ganzen Jahres unabhängig von floristischen und klimatischen Gegebenheiten gesammelt werden und einen regelrechten Trachtzyklus zeigen. Die Sammelaktivitat war im Sommer und Herbst verglichen mit den anderen Jahreszeiten größer (Fig. 3 - 5). Das Maximum in der Nektarsammelaktivität trat im allgemeinen nach dem Maximum der Pollensammelaktivität auf. Die Flugaktivität zeigte während der verschiedenen Jahreszeiten des beobachteten Jahres tolgende Aktivitätsmaxima : Sommer $(6.00,8.00,10.00$ und $16.00 \mathrm{~h})$; Regenzeit $(9.00$ und $10.00 \mathrm{~h})$; Herbst $(9.00,10.00$ und $12.00 \mathrm{~h})$; früher Winter $(9.00$ und $14.00 \mathrm{~h})$; später Winter $(11.00 \mathrm{~h})$ und Frühling (8.00 und 11.00 h) (Fig. 4).

Der Prozentsatz der Nektarsammlerinnen war während aller Jahreszeiten des Beobachtungsjahres größer als der der Pollen-, Pollen + Nektar- und Wasser-sammlerinnen. Im Prozentsatz der Nektarsammlerinnen traten verglichen mit den anderen Sammlerinnen größere Schwankungen zwischen den einzelnen Jahreszeiten auf (Fig. 6 bis 11 ).

\section{REFERENCES}

Bennetr M.F., Renner M., 1963. - The collecting performance of honeybees under laboratory conditions. Biol. Bull. Woods Hole, 125, 416-430.

Bisht D.S., PANT N.C., 1968. - Studies on the pollen gathering acitvity of the Indian honeybee, Apis cerana indica F. under Delhi conditions. Indian J. Entomol,, 30, 163-168.

Cherian M.C., Ramachandran S., Mahadevan V., 1947. - Studies in bee behaviour. Indian Bee J., 9, $116-124$.

ERICKSON E.H., Whitefoot L.O., Kissinger W.A., 1973. - Honeybees : a method of delimiting the complete profile of foraging from colonies. Environ. Entomol., 2, 531-535.

GaRY N.E., 1979. - Activities and behaviour of honeybees. From The hive and the honeybee, cd. Dadant and sons. Hamilton, Illinois : Dadant and sons.

Kerr W.E., Gonçalves L.S., Blotta L.F., Maciel H.B., 1970. - Comparative biology of Italian and African honeybees and their hybrids. Ist Congr. Bras. Apic., Florianopolis, 151-185.

Naim M., Phadke K.G., 1976. - Bee flora and seasonal activity of Apis cerana indica F. at Pusa (Bihar). Indian Bee J., 38, 13-19.

Núñez J., 1977. - Circadian variations of flight activity in colonies of Apis mellifera ligustica. J. Insect Physiol., 23, 387-392.

PARK O.W., 1926. - Water carriers versus nectar carriers. J. econ. Entomol., 19, 656-664.

Redoy C.C., 1980. - Observations on the annual cycle of foraging and brood rearing by Apis cerana indica F. colonies. J. apic. Res., 19, 17-20.

Ribbands C.R., 1953. - The behavioul and social li/e of honeybees, New York, Dover Publications, Inc.

Subbareddi C., Reddi E.U.B., Reddi N.S., 1980. - Floral reward and honeybee visitation rates in the soapnut tree. Proc. 2nd Int. Conf. on Apiculture in Tropical Climates, New Delhi (India). 